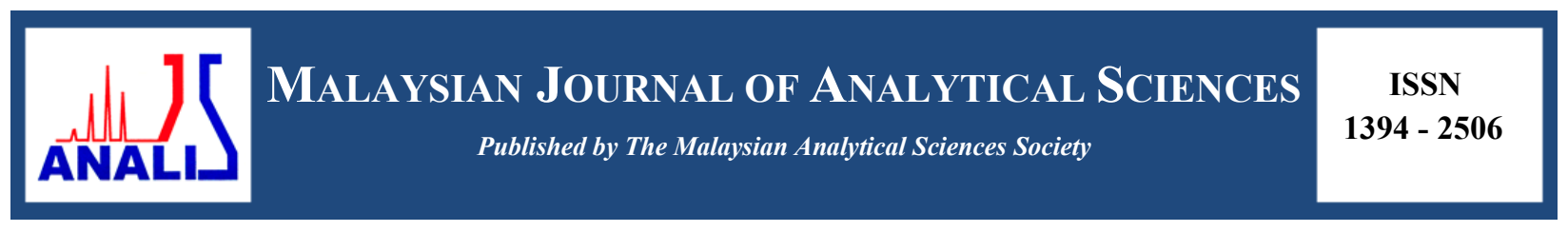

\title{
INFRA-RED INVESTIGATION ON SILICON SOLAR CELLS
}

\author{
(Kajian Inframerah ke atas Sel-sel Suria Silikon) \\ Nurfarizza Surhada Mohd Nasir, Suhaila Sepeai*, Cheow Siu Leong, Kamaruzzaman Sopian, Saleem H.Zaidi \\ Solar Energy Research Institute (SERI) \\ Universiti Kebangsaan Malaysia, 43600 UKM Bangi, Selangor, Malaysia \\ *Corresponding author: suhailas@ukm.edu.my
}

Received: 12 April 2017; Accepted: 1 September 2017

\begin{abstract}
Increasing reliance on carbon-based fossil fuel is likely to cause irreversible damage to global environment. Crystalline silicon (Si) based on pollution free photovoltaic (PV) electricity generation technology is expected to play a dominant role in this electricity generation transition from carbon to silicon. Since Si wafer represents almost $50 \%$ of the PV conversion cost, thinner wafers are highly effective at reducing the production cost. Therefore, there is an urgent need to develop alternative device configurations and processing methods for thinner Si wafer. Si wafer has to go through cleaning process, thinning process, textured process and partially transparent technique. In this work optical transmission through Si is investigated as a function of wafer thickness. For this improved performance, surface morphology, optical properties and the optical transmission near band gap is measured with custom-designed rear infra-red (IR) transmission measurement system. Si wafer with the textured surface have more light absorption than the as-cut and planar Si wafer.
\end{abstract}

Keywords: optical transmission, thin silicon wafers, infrared light, light absorption

\begin{abstract}
Abstrak
Peningkatan kebergantungan terhadap penggunaan bahan bakar berasaskan sumber karbon mengakibatkan pencemaran alam sekitar. Fotovolta (PV) sifar pencemaran berasaskan silikon kristal merupakan teknologi tenaga elektrik generasi terkini dijangkakan menjadi sumber yang mendominasi perubahan sumber bahan api berasaskan karbon kepada silikon. Tambahan pula, kepingan silikon meliputi 50\% kos keseluruhan pembuatan PV, pengurangan kos yang efektif didapati melalui penipisan kepingan.. Oleh itu, kaedah alternatif kepada pembaharuan bagi konfigurasi sistem penipisan silikon harus di cadangan. Kepingan silikon harus melalui proses pembersihan, proses penipisan, proses tekstur dan teknik separa telus. Dalam kajian hubungan di antara ketebalan kepingan silicon dan maklumat optik diteliti. Bagi meningkatkan prestasi, morfologi permukaan, sifat optik, dan penghantaran optik menghampiri jurang jalur diukur dengan menggunakan sistem pengukuran penghantaran gelombang IR.
\end{abstract}

Kata kunci: penghantaran optik, kepingan silikon nipis, cahaya inframerah, penyerapan cahaya

\section{Introduction}

Silicon wafer-based photovoltaic module production has been growing over $30 \%$ since the last decade [1]. Generally, the cost of Si accounts for almost $50 \%$ of a photovoltaic panel [2]. Historically, a pathway to reduce cost has been realized by economic use of $\mathrm{Si}$ in the form of thinner substrates; current $\mathrm{Si}$ wafer is in $150-200 \mu \mathrm{m}$ thickness [3]. Si PV technology is almost exclusive based on mono-facial solar cells in which light is incident from the front surface with the back surface completely metallized. The bifacial solar cell is an emerging solar cell configuration in which electrical grid patterns are identical on both front and back surfaces. This device 
configuration has the potential to generate more power by capturing scattered light from the rear surface than the mono-facial solae cell. The challenging problems in bifacial solar cell is to ensure that the photo-generated electronhole $(\bar{e}-h)$ pairs absorbed near the back surface are collected by the front surface emitter prior to recombination. This experiment can be done by using appropriate surface texturing methods, light trapping can be enhanced and absorption in the rear-infrared (NIR) [4-6]. The optical properties of a broad range of different bifacial configurations with varying surface morphologies and rear side reflectors have been extensively investigated in the literature. Although wafer thickness reduction translates into smaller recombination losses and large open circuit voltages; absorption is reduced as well [7].

These considerations have led to extensive research on performance limiting factors in amorphous [8], multicrystalline [9], and single crystalline solar cells [10,11]. Due to its indirect band gap, crystalline silicon has weak optical absorption particularly in the range $(\sim 900-1100) \mathrm{nm}$. Therefore, in solar cell studies aimed at increasing the efficiency, the primary goal is to enhance light absorption while minimizing recombination losses. Surface texturing aimed at enhanced absorption in silicon has been extensively investigated by geometrical optic [12]. Geometrical textures reduce reflection light into the semiconductor. Despite their effectiveness and industrial applications, geometrical texturing schemes suffer from several disadvantages that limits their effectiveness. Some of those are listed below [13]:

i) Wet-chemical alkaline anisotropic etching used to form random pyramids in (100) oriented crystal is not effective in texturing of flow cost multi-crystalline (mc-Si) wafers, ii) Anti-reflection films have a resonant structure which limits their effectiveness to a narrow range of angles and wavelength, iii) Sufficient IR absorption in thin film (< $10 \mu \mathrm{m})$ silicon solar cells is not possible with geometrical optics based texturing.

Light trapping schemes based on geometrical optics considerations have been developed for enhancing oblique coupling beyond narrow angle range of $\left(\sim 16^{\circ}\right)$ defined as $\sin ^{-1}(1 / n)$, where $n$ is the refractive index of silicon [14]. In general, the required feature dimensions for geometrical optical path length enhancement are optical wavelength, therefore their applicability to thinner wafers is impractical. Periodically textured surfaces based on diffractive [15] and waveguide optics [16] have been shown to significantly enhance optical absorption. For a weakly absorptive medium, statistical analysis by Yablonovitch [17] and optical analysis of scattering from a lambertian surface predicted absorption enhancement in textured surfaces by $\left(\sim 4 n^{2}\right)$ over a planar surface, where $n$ is the refractive index of the material. Absorption in such structure is opposed to conventional horizontal, thin-film waveguide structures as proposed by Sheng [18].

In literature application of diffractive and physical optics structures aimed enhancement of optical absorption in thin Si films and solar cells have been reported with good results [19 - 28]. Lambertian schemes and related geometrical optics-based ray tracing approached were applied to both amorphous silicon [29] and crystalline silicon solar cells [30] with successfully results. A lambertian surface capable of filling all the available $k$-space with light beams of equal intensity is difficult to achieve in practice. A close approximation is a randomly textured surface supporting sub-wavelength features. Therefore, the random surface can be described by Fourier summation-over a large number of periods. Although the resulting diffractive scattering ensures almost complete filling of the $k$-space. Light incident on such surfaces normally is diffractively scattered over a broad angular range determined by using equation 1 below

$$
\theta_{\mathrm{m}, \mathrm{i}}=\sin ^{-1}\left(m_{\mathrm{i}} \lambda / n d_{\mathrm{i}}\right)
$$

where $n, d_{\mathrm{i}}$ represents the $m^{\text {th }}$ diffraction order corresponding to the spatial period $d_{\mathrm{i}}$ and $n$ is Si refractive index. Optical path length in geometrical optics is simply the sum of number of passes through a thin film of thickness, $t$. For a single grating the total optical path length enhancement is given by summing over the lengths of all transmitted diffraction order (equation 2):

$$
d_{\mathrm{opt}}^{\text {grating }}=\sum i \gamma_{\mathrm{i}} d_{\mathrm{i}}
$$


where $\gamma_{\mathrm{i}}$ is fraction of incident energy coupled into diffractive, $d_{\mathrm{i}}$. For a normally propagating zero order, $d_{0}$ is identical to $t$; for the diffraction orders the optical path is $t / \cos \theta_{i j}$ where $\theta_{\mathrm{i}}$ the angle of propagation of the $i^{\text {th }}$ diffraction order. For a random sub-wavelength diffractive surface the total optical path length is summed over all grating $(i)$; each of which generates diffraction orders $(j)$ as defined as (equation 3 ):

$$
d_{\mathrm{opt}}^{\mathrm{random}}=\sum_{\mathrm{i}, \mathrm{j}} \gamma_{\mathrm{i}, \mathrm{j}} d_{\mathrm{i}, \mathrm{j}}
$$

Comparison of the three cases (planar, single period and random surface) illustrate that an appropriately designed random surface is highly effective in filling the $k$-space and therefore in reaching the $4 n^{2}$ enhancement limit.

For a good solar cell it is crically important that all of the incident energy to be scattered into obliquely propagating transmitted orders in order to enhance optical path length hence increase absorption rate. This can be achieved for feature dimensions either substaintially larger (Figure. 1(a)) or comparable or substaintially smaller than optical wavelength (Figure. 1 (b)). The first configuration refers to geometrical optics, the second to diffractive optics, and the third to physical optics. In the physical optics approach deeply etched subwavelength structures are created in three dimensions, on the surface and through the substrate. Rigorous coupled wave analysis [14] has been used to calculate optical absorption in these 3D grating structures. Physical optics also described in terms of subwavelength surfaces (sws) essentially acting as multi-layer anti-reflection films [31]. Structures play no role in optical path length enhancement. In this paper, near IR transmission in $(\sim 800-1700) \mathrm{nm}$ spectral range for planar and randomly textured $\mathrm{Si}$ wafers have been investigated for Si wafers with thickness of $(\sim 200 \mu \mathrm{m})$.

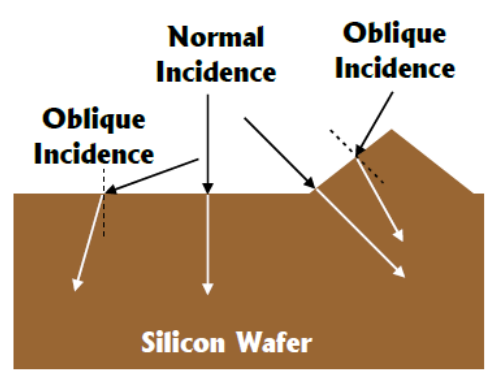

(a)

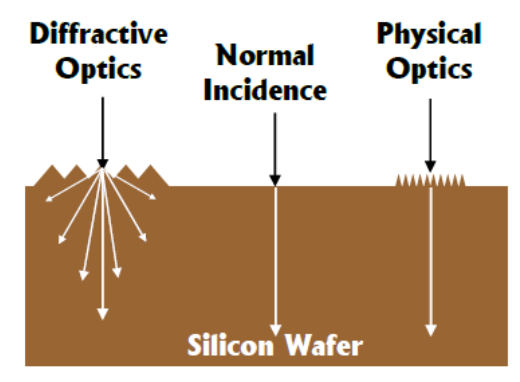

(b)

Figure 1. Schematic description of light, interaction with surface features (a) optical wavelength and (b) either or optical wavelength for convenience reflected (diffracted beams are not shown).

\section{Materials and Methods}

Single crystalline silicon (c-Si) wafer with thickness about $(\sim 200 \mu \mathrm{m})$ is used. $P$-type Si wafers with resistivity ranging between (0.5-3.0) $\Omega$.cm with doping density between $10^{10}$ to $10^{16}$ were used. The silicon $(\mathrm{Si})$ wafer was initially cleaned by dipping into solution of hydrofluoric acid (HF) and nitric acid $\left(\mathrm{HNO}_{3}\right)$ in a ratio of 1:100 for 10 minutes. After rinsing with deionized water, it was then dipped into HF and water in a ratio of 1:50 for 1 minute. The wafer was immersed in $10 \%$ potassium hydroxide $(\mathrm{KOH})$ at a temperature of $70-80{ }^{\circ} \mathrm{C}$ for 5 minutes. Subsequently, the wafer was repeatedly cleaned in $\mathrm{HF}: \mathrm{H}_{2} \mathrm{O}$ for 1 minute. Then the wafers were rinsed with deionized water for about 2 minutes and dried with nitrogen gas. Etching process led to the decrease in thickness of Si wafers. Figure 2(a) shows an etching process by using $\mathrm{KOH}$ solution. Si wafer with damage removal needs to go through the texturing process with ratio of 1:5:125. The texturing process is a combination of $4 \mathrm{~g}$ of $\mathrm{KOH}$ pallets, $20 \mathrm{ml}$ of isopropanol and $90 \mathrm{ml}$ of deionized ( DI ) water. The Si wafer will be laminated by using the laminator. Then, the laminated wafer will be transferred into a beaker which contained $10 \% \mathrm{KOH}$ solution.

The estimated time would be 1 hour and 45 minutes at the temperature of $70-80^{\circ} \mathrm{C}$. Next, the IR transmission data will be measured. Figure 2(b) shows the etching process by using $\mathrm{HF}: \mathrm{HNO}_{3}$ with a ratio of 1:10. Then, $\mathrm{Si}$ wafertextured were dipped in a solution of $\mathrm{HF}: \mathrm{HNO}_{3}$ with ratio of $1: 10$ for 1 hour and 45 minutes. Then, the wafers were 
rinsed and dried with nitrogen gas. The IR transmission data is recorded from $(600-1200) \mathrm{nm}$ wavelength with sub-wavelength $25 \mathrm{~nm}$. Figure 2(c) shows a process flow for paste Black Etching Surface (BES) paste process on silicon wafer with $200 \mu \mathrm{m}$ thickness. Next, the oxidation process was applied to the Si wafers. The time estimated to produce the oxide layer approach $350 \AA$ is 1 hour and 30 minutes at the temperature $1100^{\circ} \mathrm{C}$. The $\mathrm{Si}$ wafers size were then cut into $4 \mathrm{~cm} \times 4 \mathrm{~cm}$. The BES paste contains level of carbon black and $n$-methyl-2-pyrrolidone by EMD Chemicals Company is placed onto the mask and at the same time the Si wafer is placed under the mask. After that, the etched $\mathrm{Si}$ wafer is heated in the furnace at the temperature of $350^{\circ} \mathrm{C}$ for 90 seconds. Next, Si wafer is soaked in $1 \% \mathrm{KOH}$ for 1 minute at $40{ }^{\circ} \mathrm{C}$. After the BES paste is peeled out from the $\mathrm{Si}$ wafer, the Si wafer is placed into $10 \%$ $\mathrm{KOH}$ solution for 1 hour and 15 minutes at $70^{\circ} \mathrm{C}$. Then, the $\mathrm{Si}$ wafer is rinsed using deionized (DI) water and dried with nitrogen gas.

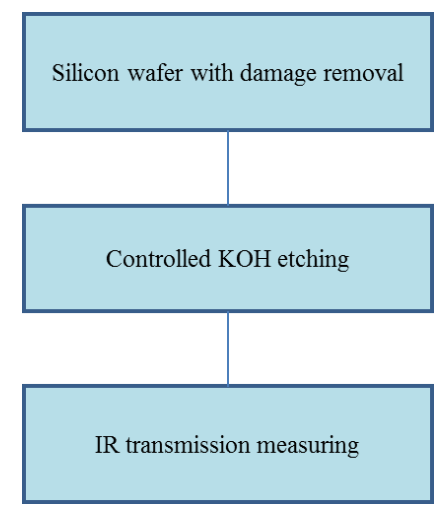

(a)

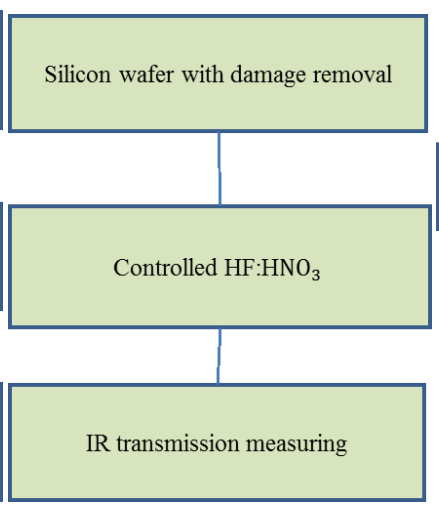

(b)

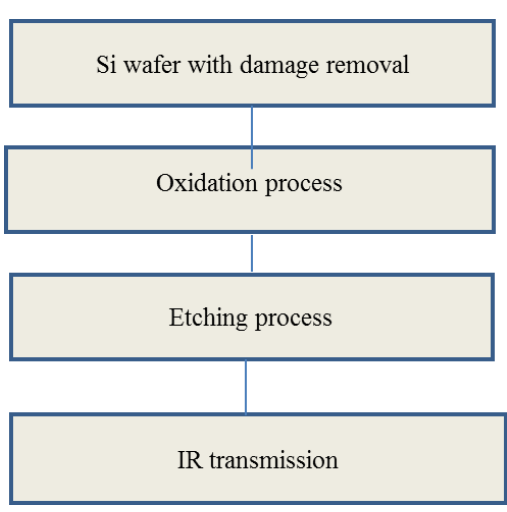

(c)

Figure 2. (a) Process flow for $\mathrm{KOH}$ etching process on silicon wafer with 200- $\mu$ m thickness (b) Process flow for $\mathrm{HF}: \mathrm{HNO}_{3}$ etching process on silicon wafer with $200-\mu \mathrm{m}$ thickness (c) Process flow for BES paste process on silicon wafer with $200-\mu \mathrm{m}$ thickness.

A simple experimental setup based on optical configuration described in Figure 3 has been developed for characterization of near IR transmission as a function of wavelength. This system is designed to measure optical transmission system in near and far infrared (IR) range specifically for the wavelength. A computer controlled IR monochromator is used to vary wavelength in the desired range. Spectrally variable light from te monochromator is incident normally on the sample under measurement (SUM). The transmitted light from the sum is collected focusing lens onto an InGaAs photodetector. The output from photodetector is connected to a lock-in amplifier, which is connected to a computer. Intensity variation as a function of wavelength is measured with a LABVIEW based computer programme.

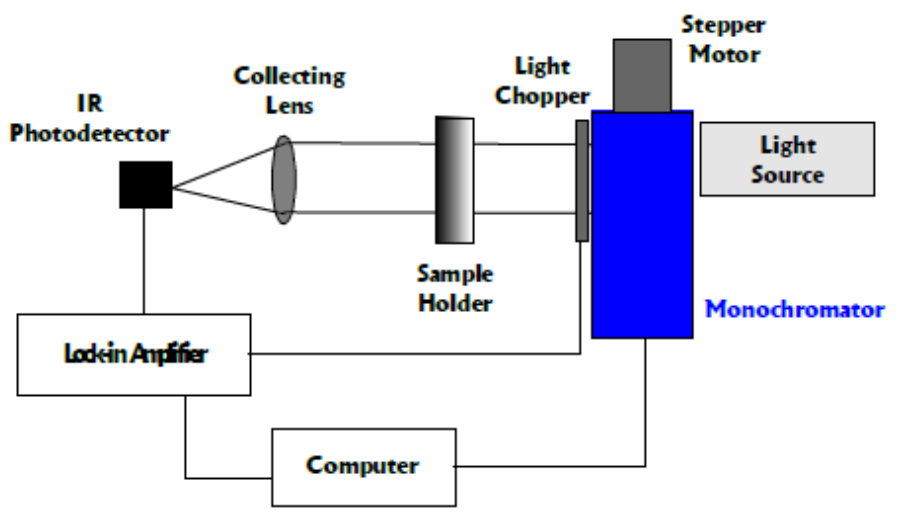

Figure 3. Schematic diagram for IR transmission measurement system 


\section{Results and Discussion}

In order to reduce the reflectivity of the surface and to trap the light in solar cell, texturing process by using $\mathrm{KOH}$ solution have developed good achievement in capturing the light.In this work, thining process include $\mathrm{KOH}$ etching pocess whereas the $\mathrm{Si}$ wafers were immersed in $10 \% \mathrm{KOH}$ solution with different time eching such as 30, 60, 90 and 180 minutes. In figure. 4 shows the surface morphology from scanning electron microscope (SEM) analysis for $\mathrm{KOH}$-etched surface. Table 1 conclude that the SEM data at 30 minutes the Si wafer reduced to 58. $4 \mu \mathrm{m}$ and the etching rate is $1.94 \mu \mathrm{m} / \mathrm{min}$. Table 2 summarize from surface profiler at 30 minutes the $\mathrm{Si}$ wafer reduced to 31.24 $\mu \mathrm{m}$ and the etching rate is $1.04 \mu \mathrm{m} / \mathrm{min}$. These etch results show that etch rate is significantly slowed as etch time increase, this may be attributted to loss of water in the solution to the evaporation resulting in a higher $\mathrm{KOH}$ concentration which in turn, slow the etch rate.
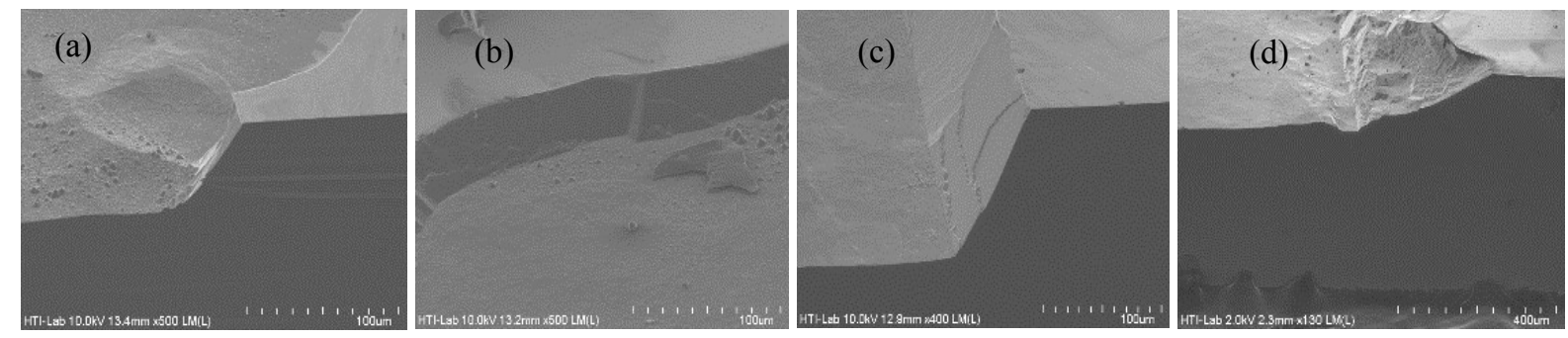

Figure 4. Topographical images for KOH-etched Si surfaces for etching times of 30 minutes (a), 60 minutes (b), 90 minutes (c) and 180 minutes (d)

Table 1. Result of the thickness for $\mathrm{KOH}$ etching vs time from SEM data

\begin{tabular}{lcc}
\hline $\begin{array}{l}\text { Samples } \\
(\text { minutes })\end{array}$ & $\begin{array}{c}\text { Thickness } \\
(\boldsymbol{\mu} \mathbf{m})\end{array}$ & $\begin{array}{c}\text { Etching Rate } \\
(\boldsymbol{\mu} \mathbf{m} / \mathbf{m i n})\end{array}$ \\
\hline 30 & 58.4 & 1.94 \\
60 & 41.3 & 0.63 \\
90 & 97.3 & 1.08 \\
180 & 135.2 & 0.75 \\
\hline
\end{tabular}

Table 2. Result of the thickness for $\mathrm{KOH}$ etching vs time from surface profiler

\begin{tabular}{lcc}
\hline $\begin{array}{l}\text { Samples } \\
\text { (minutes) }\end{array}$ & $\begin{array}{c}\text { Thickness } \\
(\boldsymbol{\mu} \mathbf{m})\end{array}$ & $\begin{array}{c}\text { Etching Rate } \\
(\boldsymbol{\mu} \mathbf{m} / \mathbf{m i n})\end{array}$ \\
\hline 30 & 31.238 & 1.04 \\
60 & 58.056 & 0.96 \\
90 & 91.862 & 1.02 \\
180 & 213.18 & 1.18 \\
\hline
\end{tabular}

Figure 5 shows $\mathrm{Si}$ wafer surface after through the $\mathrm{KOH}$ etching process. Etching of $\mathrm{Si}$ in orientation-dependent alkaline solutions is very well characterized. The etch anisotropy of the alkaline solutions basically results from the fewer surface $\mathrm{Si}-\mathrm{OH}$ bonds per unit cell on $<111>$ compared to $<100>$ and $<110>$ surfaces. Due to this, it leads to higher energy to break bonds of the $<111>$ surface $\mathrm{Si}$ atoms. This anisotropy effect is employed to generate $\mathrm{V}$ grooves in $<100>\mathrm{Si}$ wafers using openings in an appropriate mask such as an oxide layer. The wafer release two 
configurations: a) through holes and b) no holes. According to these results, it show that an oxide layer on Si wafer is not uniformly grown. Figure 5(a) shows the morphology of Si wafer at area with holes by using AMSCOPE 3.0 MD400E digital microscope and Figure 5(b) shows the morphology of Si wafer with partially holes.
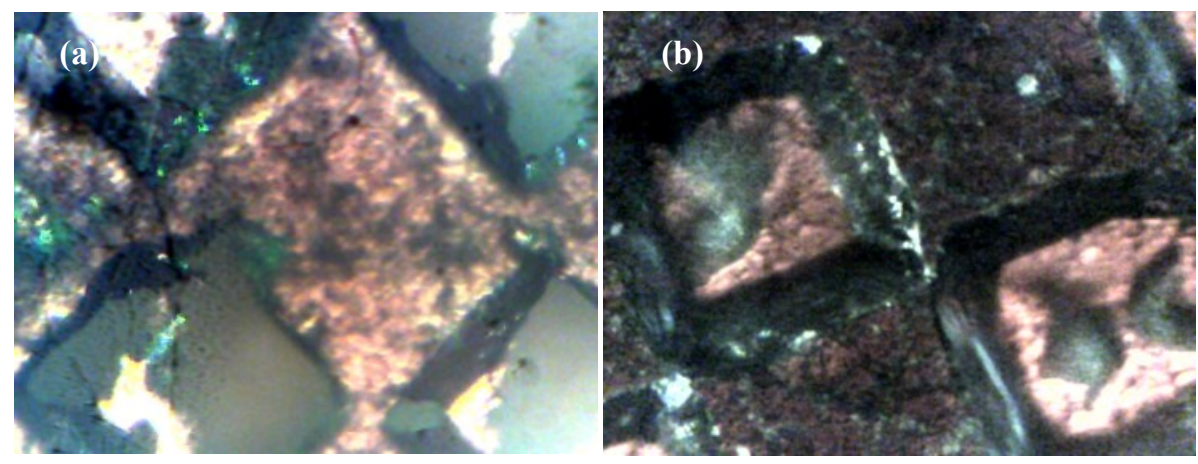

Figure 5. MD400E digital microscope pictures after through $\mathrm{KOH}$ etching process (a) the morphology of Si wafer at area with through holes and (b) morphology of Si wafer with partially holes.

Figure 6 shows plots as recorded transmission data as a function of wavelength: comparison transmission response in air and the Si wafer with damage removal known as a baseline have also been plotted. The transmission responses have been plotted on a log scale due to several orders of magnitude variation in transmitted signal. Transmission through air in (yellow line) is has the highest value. The transmission through Si wafer with holes (gray line) is second highest due to lack of absorption of wafer. However, light can be transmitted through Si wafer without reflections. Therefore, the transmission of the Si wafer is highest than planar wafers. Transmission through $\mathrm{Si}$ wafer with partially holes (orange line) can trap light and transmit less. Moreover, the Si wafer surface becomes more textured compared with holes. This is due to the increase of light absorption in a textured surface. Transmission through relatively planar polished sample (dark blue line) is lower absorption in a planar and nontextured surface. The sample thickness reaches approximately at $(\sim 180 \mu \mathrm{m})$ after going through the damage removal process. Therefore, more light will be reflected. The transmission through $\mathrm{Si}$ wafer with $\mathrm{KOH}$-textured etching process is the lowest in $1000-1200 \mathrm{~nm}$ range (bright blue). The wafer with $\mathrm{KOH}$ etching is completely textured with estimated thickness of $(\sim 80 \mu \mathrm{m})$. The absorption of incident light is enhanced due to texture-based trapping. The Si wafer with $10 \% \mathrm{KOH}$ have high quality of absorption light in IR wavelength. The surface texture also significantly enhances the light trapping in the long wavelength region, $800-1000 \mathrm{~nm}$.

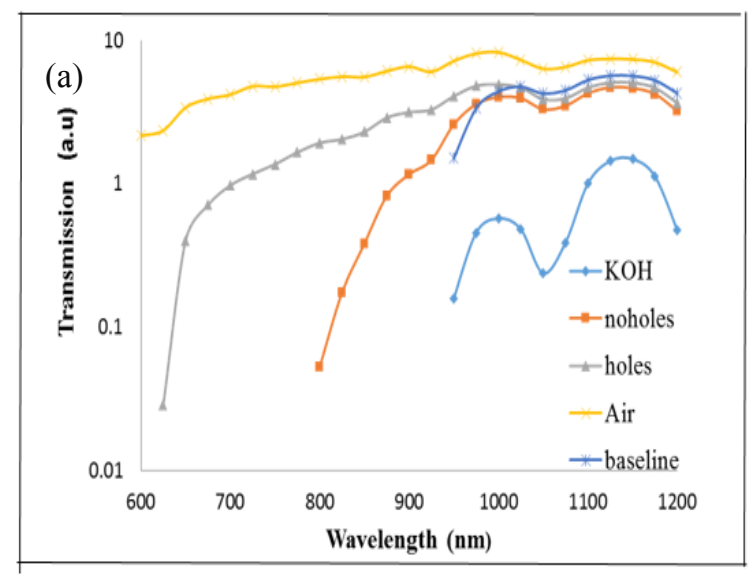




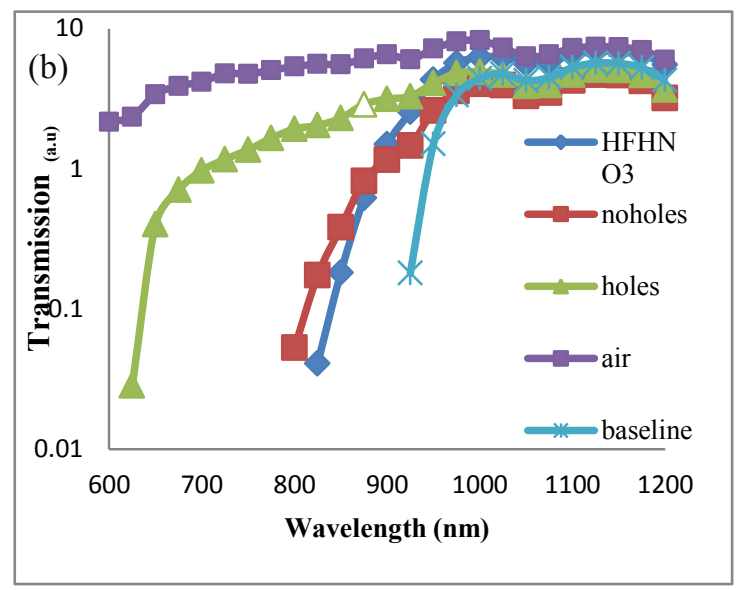

Figure 6. Comparison of optical transmission measurements a) with $\mathrm{KOH}$ and $\mathrm{BES}$ paste etching method and b) with $\mathrm{HF}: \mathrm{HNO}_{3}$ and BES paste etching method.

Figure 6(b) plots as recorded transmission data as a function of wavelength; comparison transmission response in air without $\mathrm{Si}$ wafer and the Si wafer with damage removal known as a baseline have also been plotted. The transmission responses have been plotted on a log scale orders of magnitude variation in transmitted signal. Transmission through air (yellow line) is highest. Transmission through Si wafer with holes (grey line) is lower than through air due to lack of absorption in wafer. However, light can transmit through wafer directly without reflection. Therefore, the transmission of the Si wafer is higher than planar wafers. Transmission through Si wafer with no holes (orange line) is reduced due to Si wafer surfaces. Moreover, the Si wafer surfaces had become more textured as the absorption of light increases. Transmission through $\mathrm{Si}$ wafer with $\mathrm{HF}: \mathrm{HNO}_{3}$ solution at 1:10 ratio (bright blue line) is lower due to its surface. As etching time increase, the Si wafer thickness is reduced to make it thinner. However, as etching time increased wafer starts to develop substantial texture and no longer planar. Therefore, the absorption of light is higher due to surface texturing.

\section{Conclusion}

A simple IR spectral transmission system based on InGaAs photodetector and monochromator was successfully developed for spectral optical measurement. Based on feature dimensions, incident light interaction can be described in terms of geometrical, diffractive and physical optics. The thinner, textured-Si wafer gives the lowest transmission due to a combination of low reflection and diffractive scattering. A more detailed analysis in terms of measured thickness and surface textured will be reported elsewhere.

\section{Acknowledgement}

This work was supported by the Malaysia Ministry of Science Technology and Innovation (MOSTI) and Universiti Kebangsaan Malaysia under the grant UKM-SPKP-CRIM-PK01-B001.

\section{References}

1. Maycock, P., (2003). PV market update. Renewable Energy World, 6(4): 84.

2. Munzer, K. A., Holdermann, K. T., Schlosser, R. E. and Sterk, S. (1999). Thin monocrystalline silicon solar cells. IEEE Transactions on Electron Devices, 46(10): 2055 - 2061.

3. Tiedje, T., Yablonovitch, E., Cody, G. D. and Brooks, B. G. (1984). Limiting efficiency of silicon solar cells. IEEE Transactions on electron devices, 31(5): 711 - 716.

4. Cuevas, A. (1999). The effect of emitter recombination on the effective lifetime of silicon wafers. Solar Energy Materials and Solar Cells, 57(3): 277 - 290.

5. Pan, A. C., Del Cañizo, C. and Luque, A. (2009). Characterization of up-converter layers on bifacial silicon solar cells. Materials Science and Engineering: B, 159: 212 - 215. 
6. Frank, J., Rüdiger, M., Fischer, S., Goldschmidt, J. C. and Hermle, M. (2012). Optical simulation of bifacial solar cells. Energy Procedia, 27: 300 - 305.

7. Yamamoto, K., Yoshimi, M., Suzuki, T., Nakata, T., Sawada, T., Nakajima, A. and Hayashi, K. (2000). Largearea and high efficiency a-Si/poly-Si stacked solar cell submodule. In Photovoltaic Specialists Conference, 200 0. Conference Record of the Twenty-Eighth IEEE: pp. 1428 - 1432.

8. Hebling, C., Glunz, S. W., Schumacher, J. O. and Knobloch, J. (1997). High efficiency (19.2\%) silicon thinfilm solar cells with interdigitated emitter and base front-contacts. In 14th European Photovoltaic Solar Energy Conference, 2318.

9. Yamamoto, K. (1999). Very thin film crystalline silicon solar cells on glass substrate fabricated at low temperature. IEEE Transactions on Electron Devices, 46(10): 2041 - 2047.

10. Miles, R. W., Zoppi, G. and Forbes, I. (2007). Inorganic photovoltaic cells. Materials Today, 10(11): 20 - 27.

11. Green, M. A. (1995). Silicon Solar Cells: Advanced Principles and Practice. Bridge Printery, Sydney.

12. Green, M. A. and Keevers, M. J. (1995). Optical properties of intrinsic silicon at 300 K. Progress in Photovoltaics: Research and Applications, 3(3): 189 - 192.

13. Craighead, H. G., Howard, R. E. and Tennant, D. M. (1980). Textured thin-film Si solar selective absorbers using reactive ion etching. Applied Physics Letters, 37(7): 653 - 655.

14. Southwell, W. H. (1983). Gradient-index antireflection coatings. Optics Letters, 8(11): $584-586$.

15. Heine, C. and Morf, R. H. (1995). Submicrometer gratings for solar energy applications. Applied Optics, 34 (14): $2476-2482$.

16. Azhari, A. W., Goh, B. T., Sepeai, S., Khairunaz, M., Sopian, K. and Zaidi, S. H. (2013). Synthesis and characterization of self-assembled, high aspect ratio nm-scale columnar silicon structures. In Photovoltaic Specialists Conference (PVSC), 2013 IEEE $39^{\text {th }}$ : pp. 0530 - 0534.

17. Yablonovitch, E. (1982). Statistical ray optics. Journal of the Optical Society of America, 72(7): 899 -907.

18. Sheng, P. (1984). Optical absorption of thin film on a Lambertian reflector substrate. IEEE Transactions on Electron Devices, 31(5): $634-636$.

19. Zaidi, S. H., Ruby, D. S., DeZetter, K. and Gee, J. M. (2002). Enhanced near IR absorption in random, RIEtextured silicon solar cells: The role of surface profiles. In Photovoltaic Specialists Conference, 2002. Conference Record of the Twenty-Ninth IEEE: pp. $142-145$.

20. Zaidi, S. H. and Brueck, S. R. (1997). Si texturing with sub-wavelength structures. In Proceedings of the 1997 IEEE 26th Photovoltaic Specialists Conference. IEEE: pp. $171-174$.

21. Zaidi, S. H., Gee, J. M. and Ruby, D. S. Ruby (2000). Plama texturing for multicystalline Si solar cells. In Proceedings of the 2000. Conference Record of the Twenty-Eighth IEEE Photovoltaic Specialists: pp. 75 - 78.

22. Zaidi, S. H., Matzke, C., Koltunski, L. and DeZetter, K. (2005). Absorption in thin Si films with randomly formed subwavelength structures. In Photovoltaic Specialists Conference, 2005. Conference Record of the Thirty-first IEEE: pp. 1145 - 1148.

23. Jahanshah, F., Prinja, R., Anderson, J., Manginell, R., Amin, N., Sopian, K. and Zaidi, S. H. (2008). An investigation of three-dimensional texturing in silicon solar cells for enhanced optical absorption. In Photovoltaic Specialists Conference, 2008. $33^{\text {rd }}$ IEEE: pp. $1-5$.

24. Zaidi, S. H., Marquadt, R., Minhas, B. and Tringe, J. W. (2002). Deeply etched grating structures for enhanced absorption in thin c-Si solar cells. In Photovoltaic Specialists Conference, 2002. Conference Record of the Twenty-Ninth IEEE: pp. 1290 - 1293.

25. Zaidi, S. H., Ruby, D. S. and Gee, J. M. (2001). Characterization of random reactive ion etched-textured silicon solar cells. IEEE Transactions on Electron Devices, 48(6): 1200 - 1206.

26. Sandoval, S. G., Khizar, M., Modisette, D., Anderson, J., Manginell, R., Amin, N., Sopian, K. and Zaidi, S. H. (2010). Optical absorption in microstructured crystalline silicon thin films. In Photovoltaic Specialists Conference (PVSC), $201035^{\text {th }}$ IEEE: pp. $001597-001600$.

27. Azhari, A. W., Goh, B. T., Sepeai, S., Khairunaz, M., Sopian, K. and Zaidi, S. H. (2013). Synthesis and characterization of self-assembled, high aspect ratio nm-scale columnar silicon structures. In Photovoltaic Specialists Conference, 2013 IEEE $39^{\text {th }}$ : pp. $0530-0534$.

28. Deckman, H. W., Wronski, C. R., Witzke, H. and Yablonovitch, E. (1983). Optically enhanced amorphous silicon solar cells. Applied Physics Letters, 42(11): 968 - 970.

29. Campbell, P. and Green, M. A. (1987). Light trapping properties of pyramidally textured surfaces. Journal of Applied Physics, 62(1): $243-249$. 
30. Goetzbeger, A. (1981): Optical confinement in thin Si solar celss by diffuse back reflectors. Proceeding of the $15^{\text {th }}$ IEEE Photovoltaic Specialist Conference: pp. $867-870$.

31. Zubel, I. and Kramkowska, M. (2001). The effect of isopropyl alcohol on etching rate and roughness of $\left(\begin{array}{lll}1 & 0 & 0\end{array}\right)$ Si surface etched in KOH and TMAH solutions. Sensors and Actuators A: Physical, 93(2): 138 - 147. 